\title{
ANALISIS KEBIJAKAN IMPOR BERAS 1 JUTA TON OLEH PEMERINTAH INDONESIA: DATA DAN ANALISIS MEDIA SOSIAL
}

\author{
Zahra Mahreva Basuki ${ }^{1}$, Rizky Juda Putra Hidayat*2, Puji Susilo Asih ${ }^{3}$, \\ Iradhad Taqwa Sihidi ${ }^{4}$ \\ Program Studi Ilmu Pemerintahan, Universitas Muhammadiyah Malang \\ Email :rizkyjda27@gmail.com
}

\begin{abstract}
Abstrak
Rencana impor beras yang akan dilakukan oleh pemerintah Indonesia menjadi isu yang sangat menarik untuk diskusikan mengingat Indonesia yang dikenal sebagai negara agraris. Berdasarkan data yang ditunjukkan oleh BPS pada tahun 2017, sekitar 29,76 \% penduduk Indonesia berprofesi sebagai petani. Artinya ketika kegiatan impor beras tetap dilakukan, maka kesejahteraansebanyak 31, 68 juta orang (petani) mengalami penurunan. Penelitian ini bertujuan untuk menganalisis terkait rencana pemerintah Indonesia untuk mengimpor beras sebanyak 1 juta ton, dari perspektif masyarakat yang disarkan pada data serta analisis pada media sosial. Sedangkan data dan analisis sosial media dilihat pada (Twitter) yang diperoleh melalui Drone Emprit pada periode 13-19 Maret 2021. Hasil yang ditemukan berdasarkan data yang ditampilkan oleh Drone Emprit menujukkan bahwa isu atau rencana impor beras sebanyak 1 juta ton menjadi sebuah kebijakan yang mengundang banyak pro-kontra di masyarakat. Kebijakan untuk impor beras ini ditolak keras oleh mayoritas masyarakat Twitter sebab petani akan memasuki panen raya, yang mana ketika impor beras tetap dilanjukan maka yang terjadi adalah menurunnya harga jual beras dari petani sehingga berkonsekuensi pada kerugian beruntun yang dialami petani.
\end{abstract}

Kata Kunci/: Impor Beras, Kebijakan, Drone Empirit, Petani

\begin{abstract}
The rice import plan to be carried out by the Indonesian government is a very interesting issue to discuss considering that Indonesia is known as an agricultural country. Based on data shown by BPS in 2017, around $29.76 \%$ of Indonesia's population works as farmers. This means that when rice import activities are carried out, the welfare of 31.68 million people (farmers) will experience a decline. This study aims to analyze the Indonesian government's plan to import 1 million tonnes of rice, from the perspective of the community that is broadcast on the data and analysis on social media. Meanwhile, data and social media analysis can be seen on (Twitter) obtained through Drone Emprit in the period 13-19
\end{abstract}


March 2021. The results found based on the data displayed by Drone Emprit show that the issue or plan to import 1 million tons of rice is an inviting policy. many pros and cons in society. This policy for rice imports was vehemently rejected by the majority of the Twitter community because farmers will enter the harvest season, where when rice imports continue, what happens is a decrease in the selling price of rice from farmers, resulting in consecutive losses experienced by farmers.

Keywords: Rice Imports, Policies, Drone Emprit, Farmers

\section{PENDAHULUAN}

Indonesia merupakan negara agraris dengan sebagian besar penduduknya bekerja dalam sektor pertanian (Ikhsani et al., 2020). Fakta ini berkorelasi langsung pada predikat Indonesia sebagai negara dengan tingkat konsumsi beras nomor empat terbesar di dunia. Konsumsi beras penduduk Indonesia mencapai $139 \mathrm{~kg} / \mathrm{kapita}$ setiap tahunnya. Dengan laju pertumbuhan penduduk yang terus tumbuh menyebabkan kebutuhan beras akan terus meningkat di setiap tahunnya (Somantri et al., 2020) yang salah satunya dipenuhi melalui mekanisme impor (Paipan \& Abrar, 2020).

Sebagai negara agraris, kontribusi pertanian sangat signifikan. Pertanian beras bagi Indonesia adalah salah satu sektor unggulan yang dapat memegang peran penting dalam pemenuhan kebutuhan dalam negeri, terutama pada kebutuhan pangan (Sa'diah \& Tamami, 2020). Beras merupakan kebutuhan pokok yang menjadi kebutuhan sekitar $78 \%$ penduduk Indonesia untuk memenuhi asupan energi setiap hari terutama asupan karbohidrat. Beras menjadi kebutuhan pangan yang sangat penting bagi masyarakat Indonesia karena dalam dengan tingkat konsumsi 111, 58 Kilogram (Kg) per Kapita per Tahun (Timorria, 2019) Dengan jumlah penduduk yang semakin bertambah pada setiap tahunnya, mengakibatkan meningkat pula kebutuhan akan persediaan beras untuk asupan pangan masyarakat Indonesia (Sains et al., 2021).

Pemerintah sampai saat ini masih bercita-cita untuk dapat menjadikan Indonesia sebagai Lumbung Pangan Dunia pada tahun 2045. Prioritas pertama dalam mewujudkan cita-cita tersebut ialah mewujudkan swasembada pangan, terutama beras (Widyawati et al., 2014). Perlu di ingat bahwasanya pada tahun 
2005 Indonesia pernah memasuki peringkat ketiga setelah China dan India sebagai produsen padi terbesar (Febryati, 2016). Maka, Rencana impor beras yang akan dilakukan oleh pemerintah Indonesia di tengah petani yang hendak memasuki panen raya adalah sebuah ironi pada eskpektasi tersebut sehingga mendapat respon beragam baik pro maupun kontra di publik.

Paradoks tersebut terekam karena perencanaan impor beras 1 juta ton tersebut kemudian tidak dibarengi dengan realitas yang ada (Sari, 2014) yakni ketercukupan stok beras dalam negeri salah satunya karena telah memasuki musim panen. Akibat selanjutnya, ketika rencana impor beras baru sebatas wacana belum dieksekusi harga jual beras dari petani telah jatuh (Febriaty, 2016). Alhasil kesejahteraan para petani kian dipertanyakan.

Dilain sisi presiden Joko Widodo juga pernah menggaungkan terkait food eastate, sebuah program nasional yang dirancang pemerintah dengan maksud untuk meningkatkan kesejahteraan para petani. Cita-cita yang sulit terealisasi memang mengingat dibidang pertanian salah satunya karena efek perubahan iklim membuat produksi beras dalam negeri terus menyusut (Rondhi et al., 2019). Ini ditambah bahwa kebijakan anti impor beras lebih bersifat retorika populis untuk kepentingan elektoral (Davidson, 2018) yang tidak dikongkritkan seperti yang dilakukan jokowi salah satunya karena derasnya tarik ulur kepentingan.

Ekspektasi tersebut kemudian menjadi kontraproduktif dengan wacana impor beras 1 juta ton beras karena kesejahteraan petani akan semakin sulit terwujud. Inkonsistensi sikap dan rencana kebijakan inilah yang menimbulkan kegeraman bergelombang publik yang merasa pemerintah tidak berpihak pada nasib petani dalam negeri dan akan semakin memperlebar kesenjangan sosial di Indonesia.

Berdasakan data yang disajikan oleh Badan Pusat Statistik (BPS) yang dikutip dalam lamaan databoks.katadata.co.id menunjukkan bahwasanya pada tahun 2020 per Agustus jumlah penduduk yang bekerja sebanyak 128,5 juta orang (Annur, 2020). Dari jumlah tersebut sebanyak 38,83 juta orang atau sekitar 29,76 $\%$ bekerja sebagai petani. Artinya, rencana kebijakan impor ini punya dampak sangat signifikan terhadap kualitas kesejahteraan petani. 
Urgensi kegiatan impor dapat dilakukan dengan melihat beberapa faktor atau alasan salah satunya adalah terakait kapasitas produksi beras dan konsumsi beras (Darwanto \& Rahayu, 2017). Ketika jumlah produksi beras dalam negeri masih dinilai cukup untuk memenuhi kebutuhan pangan atau konsumsi beras, maka seharusnya rencana impor beras tidak perlu dilakukan. Rencana impor beras yang hendak dilakukan oleh pemerintah Indonesia ini tidak sejalan dengan realitas yang ada karena stok beras dalam negeri masih mencukupi.

Sebagaimana yang diwartakan dalam viva.co.id yang menyampaikan bahwasanya derektur utama Perusahaan Umum Badan Urusan Logistik (Bulog), yakni Budi Waseso mengungkapkan bahwa jumlah atau stok beras yang di impor pada tahun 2017 masih banyak. Persediaan beras di gudang masih mencapai angka 883.585 ton per 14 Maret 2021 (Prasetya \& Yudha, 2021). Bulog berusaha menolak kegiatan impor beras dalam waktu dekat sebab persediaan beras hasil impor di tahun 2017, 2018, masih cukup banyak. Yang ditakutkan adalah ketika kegiatan impor beras ini tetap dilakukan maka mutu beras yang belum dikeluarkan semakin menurun. Dengan melihat usia beras yang lebih dari dua tahun tersebut, menjadi sebuah urgensi untuk mengeluarkan beras dari gudang.

Namun disisi lain ketika pemerintah menerapkan kebijakan untuk melakukan pembatasan impor beras yang terjadi adalah meningkatnya angka kemiskinan. Hal ini disebabkan oleh adanya letak geografis Indonesia yang sulit untuk melakukan swasembada pangan (Kusumah, 2019). Akan tetapi jika dianalisis kembali pada masa orde baru atau dimasa kepemimpinan Soeharto Indonesia sempat mengalami swasembada pangan. Hal ini sebagaimana yang dijelaskan oleh (Di et al., 2019) bahwa Indonesia pada tahun 1980 an pernah menjadi salah satu negara pengekspor beras terbesar setelah image nya yang dikenal sebagai negara pengimpor beras terbesar di dunia. Dengan demikian maka seharusnya ketika sector pertanian benar-benar dimaksimalkan dan dimasifkan dengan melihat tenaga kerja dibidang pertanian yang menjadi mayoritas matapencaharian masyarakat Indonesia, maka tidaklah sulit untuk mencapai titik swasembada pangan. Ketika hal demikian terjadi maka realitas akan menampilkan 
kesejahteraan petani meningkat kemudian angka kemiskinanpun mengalami penurunan.

Artikel ini selanjutnya melakukan elaborasi secara kritis terhadap rencana Impor beras yang dilakukan pemerintah dalam perspektif publik. Bagaimana respon publik terhadap kebijakan kontroversi ini, apakah mendukung atau menolak dengan argumentasinya masing-masing. Polarisasi tersebut dapat direkam melalui perbincangan di media sosial yakni Twitter, salah satu sarana bagi public untuk mengantrikulasikan pandangan dan sikap politiknya terhadap sebuh kebijakan.

Dalam konteks demokrasi, Media sosial menjadi ruang proses demokratisasi (Best \& Meng, 2015; Placek, 2017; Salahudin et al., 2020). Didalamnya terjadi proses deliberasi publik (Ceron \& Memoli, 2016) karena menyediakan keterlibatan politik dalam isu-isu tertentu secara egaliter dan komunikatif (Justwan et al., 2018;Lee et al., 2018). Media sosial dapat menjadi alat untuk memobilisasi protes terhadap kebijakan negara (Chrona \& Bee, 2017). Ada debat publik yang berlangsung dua arah dan tanpa batas didalamnya (Wischmeyer, 2019). Kajian (Jha \& Kodila-Tedika, 2020) menunjukan secara keseluruhan meskipun dengan skala dan nilai yang beragam ada korelasi kuat antara penggunaan media sosial bagi proses konsolidasi demokrasi di 125 negara

Media sosial merupakan salah satu konten internet yang paling banyak digunakan manusia untuk berinteraksi secara tidak terbatas (Loilatu et al., 2021; Juditha, 2014; Amrullah et al., 2016; Purnomo et al., 2021). Media sosial adalah media yang isinya diciptakan dan didistribusikan melalui interaksi sosial menunjukkan bahwa media sosial di Indonesia dapat memobilisasi orang, namun belum mampu mendorong representasi demokratis (Galuh, 2016).

Salah satu media sosial yang dimaksud adalah Twitter. Salah satu kegunaanya memfasilitasi publik untuk menyampaikan kritik, saran dan opini terhadap sebuah hal (Tika Ardillaning Pratiwi, Burhan Bungin, 2015). Twitter menjadi arena memperbicangkan membincangkan isu-isu politik (Adinugroho et al., 2017) dan mampu mendorong tercipatnya political engganment (Daniels, 2016). 
Twitter merupakan sebuah media sosial yang sangat populer di Indonesia. Hal ini dapat dilihat dari jumlah pengguna Twitter yang mencapai 19,5 juta pengguna dari total 330 juta pengguna di dunia. Kata yang terkandung dalam Twitter merupakan bahasa alami manusia yang merupakan bahasa dengan struktur kompleks (Astiningrum et al., 2020). Kebiasaaan masyarakat mengutarakan pendapatnya melalui media sosial terutama Twitter dalam menanggapi kejadian atau hal-hal yang terjadi di lingkungan sekitarnya dapat menjadi salah satu acuan untuk mengetahui sentimen masyarakat terhadap lingkungan atau kota tempat tinggal masyarakat tersebut berupa kritik maupun saran (Hasfi et al., 2017).

Selanjutnya seperti telah ditegaskan di awal, rencana impor beras yang akan dilakukan pemerintah diperbicangkan secara intensif oleh publik lewat Twitter. Netizen (publik) menyampaikan respon pada isu tersebut yang dikerucutkan menjadi dua sisi: mendukung dan menolak. Melalui perbincangan di Twitter dengan rentang waktu 13-19 Maret 2021 diperoleh pemetaan mengenai respon publik. Data primer yang diambil dari Drone Emprit kemudian dianalisa untuk melihat lebih jauh proses polarisasi pendapat tersebut. Penelitian ini akan mengelaborasi percakapan terkait isu impor beras saat petani sedang panen raya menggunakan data dari Drone Emprit yang menekankan pada percakapan warganet di media sosial Twitter dalam bentuk tren dan volume percakapan, top tweet dari waktu ke waktu, tren berita online, sebagian besar status retweet dan gambar terkait

Artikel ini bersifat deskriptif kualitatif. Metode penelitian kualitatif yang digunakan dalam penelitian ini adalah studi literatur. Data yang dianalisis dalam penelitian ini berupa percakapan warganet mengenai topik Sentimen Impor Beras di Indonesia yang diambil dari Drone Emprit Universitas Islam Indonesia (Rahman, 2021) dalam membaca percakapan warganet di media sosial, yang mana dalam hal ini adalah Twitter selama bulan Maret 2021 telah mengonfirmasi bahwa media sosial bisa digunakan dalam menganalisis opini publik yang kekinian atau sedang berkembang saat ini. Sedangkan, proses pelacakan dari percakapan para warganet melalui beberapa tahapan, diantaranya; Pertama, menganalisis seluruh klaster dari percakapan warganet berdasarkan kata kunci 
Impor Beras dan Nilai Tukar Petani. Kedua, menentukan rentang waktu percakapan warganet. Ketiga, menganalisis kata kunci melalui Social Network Analysis (SNA) dan kemudian di uraikan berdasarkan top influencers, buzzer, dan followers. Keempat, memilah percakapan berdasarkan jumlah retweet, mention, penggunaan konten dan tagar yang digunakan. Terakhir, menganalisis emosi publik yang dominan dalam percakapan tentang impor beras.

. Selanjutnya dilakukan analisis terhadap fakta-fakta yang didapatkan dari beberapa media berita online untuk menambah elaborasi dan penjelasan dari temuan-temuan yang disajikan dalam analisis data Drone Emprit. Data analisis yang disajikan oleh Drone Emprit merupakan kumpulan tweets sejak tanggal 13 19 Maret 2021 hingga mencapai 34.794 tweets. Temuan ini membenarkan antusiasme warganet dalam berkomentar pada pembahasan terkait percakapan dengan isu tersebut.

\section{PEMBAHASAN}

Dua dalih utama yang digunakan pemerintah untuk memuluskan rencana impor beras 1 Juta ton yakni mencukupi ketersediaan beras dalam negeri dan melawan mafia beras. Konteks kebutuhan tinggi dalam negeri ini disebarluaskan melalui narasi di gambar 1

\section{Gambar 1.}

Narasi urgensi impor beras

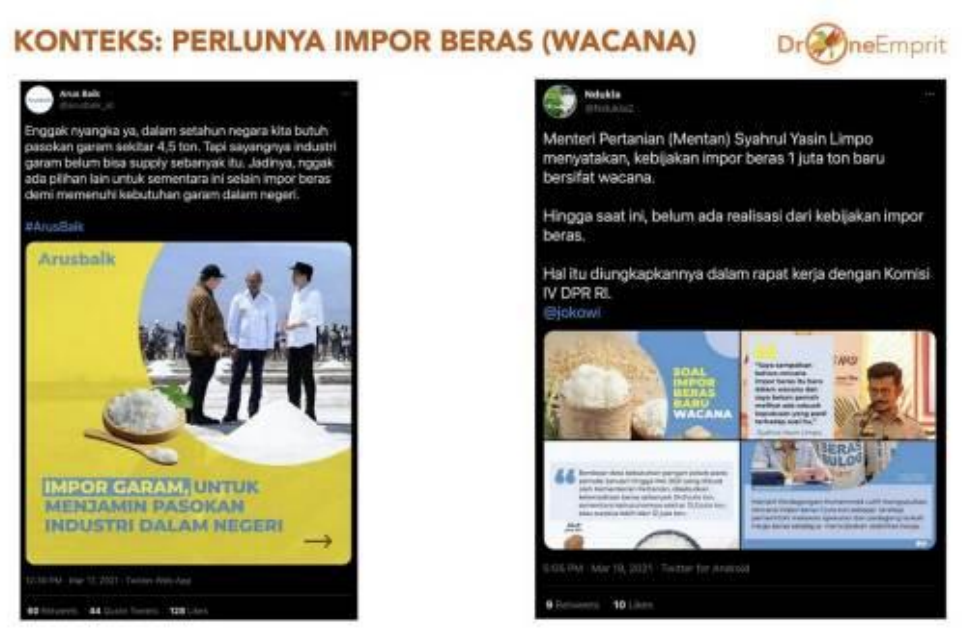

Sumber: diambil dari Drone Emprit

Jurnal Academia Praja Volume 4 Nomor 2 - Agustus 2021 
Salah satu alasan negara melakukan impor adalah untuk mencukupi kebutuhan dalam negeri, jika dalam konteks ini kita berbicara terkait isu impor beras sebanyak 1 juta ton, yang dimana diklaim sebagai bentuk upaya untuk mencukupi kebutuhan yang tinggi, kemudian disebut juga impor ini dilakukan juga sebagai bentuk melawan mafia. Namun yang kemudian menjadi ramai diperbincangkan di dalam forum online di media sosial seperti halnya Twitter, adalah impor ini dilakukan disaat petani local mendekati mangsa panen raya. Disatu sisi kapasitas beras di gudang bulog masih menumpuk belum terdistribusikan dan kondisi kualitasnya kian menurun. Logikanya ketika pemerintah membuka kran impor beras disaat petani local mendekati panen raya dan kemudian ketika beras impor masuk dengan harga jauh lebih rendah dibandingan harga beras dari petani, maka rugilah petani lokal.

Lantas kemudian jika pemerintah mengatakan impor beras ini dilakukan sebagai strategi untuk melawan mafia, maka akan berbanding terbalik dengan fakta yang terjadi bahwasanya peluang para mafia bermain adalah pada kegiatan impor itu sendiri. Dengan mengambil keuntungan disetiap kilogramnya, hal ini dikarenakan disetiap kilogram beras terdapat fee yang diperoleh, yang dijadikan sebagai lahan untuk mengambil keuntungan. Maka dari itulah banyak para tokoh ataupun influencer yang ramai-ramai menolak isu adanya impor beras yang hendak dilakukan pemerintah. Jika fakta bahwa stok beras digudang bulok masih menumpuk ditambah dengan musim panen raya tiba, dan dari keberadaan beras dalam negeri masih cukup untuk mencukupi kebutuhan pangan, lantas untuk apa impor dilakukan. Kegiatan impor beras ini akan sangat merugikan bagi petani ataupun negara sendiri jika tetap dilaksanakan. Petani akan mengalami kerugian jika beras impor yang masuk memiliki harga jual yang lebih rendah dari beras petani loka. Sedangkan negara akan sangat dirugikan jika kegiatan impor beras ini sebetulnya tidaklah perlu dilakukan sebab persedian beras dalam negeri masih banyak dan mencukupi. Akibat yang diterima negara ketika impor tetap dilakukan adalah devisa negara kian berkurang, sedangkan negara minim melakukan kegiatan ekspor yang dapat mengahsilkan devisa negara. 
Untuk meredam gejolak dan protes publik yang telah masiv di media sosial, pemerintah selanjutnya mengatakan hal tersebut masih sebatas wacana. Strategi tersebut dilakukan pemerintah untuk sentimen minor publik dengan menyatakan kebijakan tersebut sembari melihat momentum yang pas untuk mengambil keputusan akhir. Pola seperti ini cukup khas dalam manajemen isu kebijakan publik

Selanjutnya, melalui Twitter respon publik dapat dilacak intensitasnya. Secara bertahap dan bergelombang, ketika isu ini telah muncul dalam isu publik, 13 Maret isu ini belum menjadi isu utama yang diperbicangkan oleh netizen Twitter. Isu nya yang terus menghangat setiap hari semakin direspon oleh banyak baik di media sosial maupun media elektronik, topik ini trending pada 15 maret dan mencapai puncaknya pada 16 maret 2021. Ini tidak terlepas dari pernyataan Budi Waseso sebagai Kepala Bulog yang secara tegas menolak wacana ini yang diapresiasi positif oleh publik. Gambar 2 berikut ini menunjukan tren perjalanan isu tersebut yang jika ditotal sampai 19 maret terakumulasi hingga 34k Twitter, 3,8k News.

\section{Gambar 2.}

Tren dan Volume perbincangan

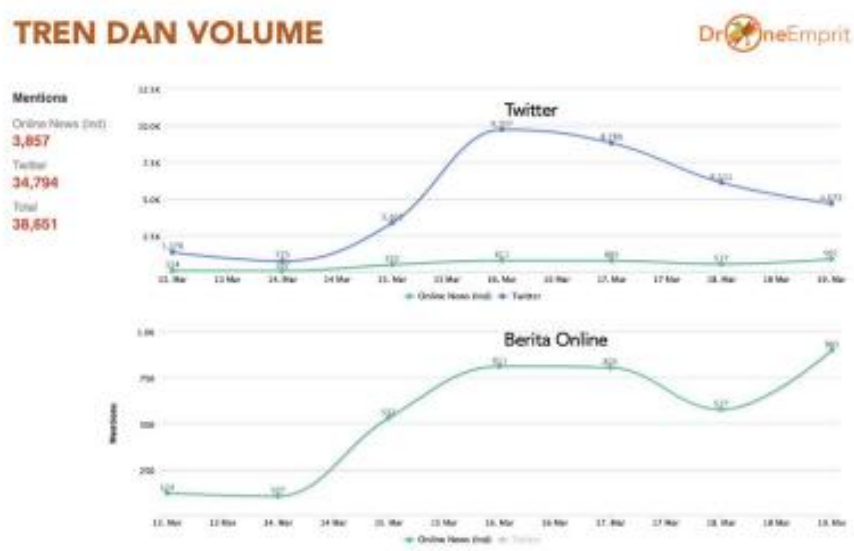

Sumber: diambil dari Drone Emprit

Gambar 2 juga menunjukan, pada media berita online, isu akan impor beras mulai muncul sejak tanggal 13 Maret dengan mention sebanyak 124 dan isu ini mulai naik pada tanggal 15 Maret yang mencapai 532 mention dan puncaknya ada pada tanggal 19 Maret dengan jumlah sebanyak 901 mention. Sehingga total 
percakapan terkait isu impor beras sejak tanggal 13 Maret hingga 19 Maret adalah sebanyak38.651 yang terbagi dalam 2 kluster; yakni sebanyak 34.794 mention di media sosial Twitter, dan 3.857 mentiondi media berita online.

Percakapan mengenai isu impor beras diketahui sejak tanggal 13 Maret 2021. Data yang diperoleh berasal dari Drone Emprit dalam menganalisis percakapan menggunakan kata kunci "Impor Beras". Percakapan terkait isu impor beras ini rupanya mendapatkan penolakan atau kontra dari warganet. Hal ini dapat dilihat dari top twit yang didominasi oleh cuitan beberapa top influencers diantaranya seperti: @fadlizon, @ susipudjiastuti, @ ridwankamil, @na_dirs, @msaid_didu, @ustadtengkuzul,dll (gambar 3)

Semuanya mengungkapkan penolakan atas rencana impor ini. Akun @ fadlizon memberikan umpan cuitan berupa penolakan atas rencana impor beras karena dianggap akan merusak kehidupan petani, yang kemudian di dukung oleh warganet dengan akun @0k1n9f4t1Ra7a yang ikut mempertanyakan nasib hasil panen petani dalam negeri.

Penolakan terhadap isu impor beras juga disampaikan oleh akun @ susipudjiastuti dengan turut meminta dukungan bagi Kabulog untuk tidak melakukan impor beras karena masyarakat petani sedang panen. Cuitan ini di dukung oleh akun@ustadtengkuzul yang menyebutkan sedikitnya ada cadangan beras di Bulog dan ada stok sebanyak 25 juta ton beras di Kementan.

Petani Jawa Barat menyampaikan aspirasi nya lewat zoom meetings agar membatalkan wacana impor beras. Twitter: @ ridwankamil 17/Mar/2021 17:24 WIB. Cuitan ini mendapat dukungan dari akun@na_dirs yang turut berkomentar bahwa nasip petani juga perlu diperhatikan.

Negara kalah melawan mafia beras sehingga berencana untuk impor beras dengan dalih untuk menghadapi mafia dengan mengorbankan petani. Hingga memberi penawaran agar petani saja yang menghadapi mafia. Twitter: @ msaid_didu 18/Mar/2021 19:14 WIB. 


\section{Gambar 3.}

Perjalanan Top Twit

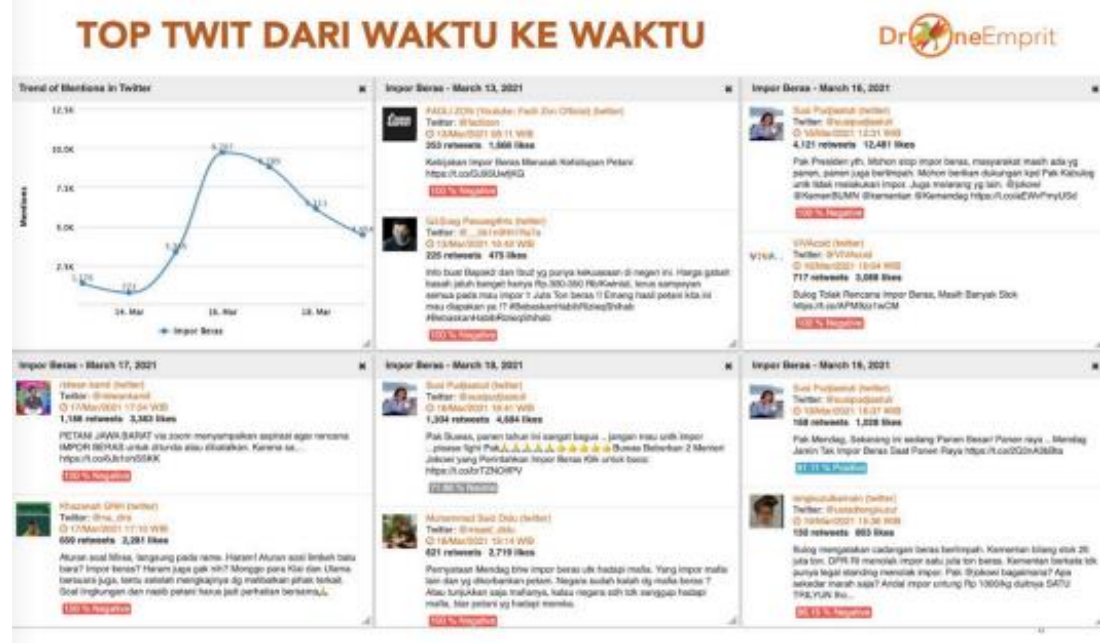

Sumber: diambil dari Drone Emprit

Percakapan warganet terkait tema impor beras ini menjadi viral di media berita online tanggal 19 Maret ketika tren berita di sosial media sudah turun. Media berita online mengangkat pendapat dari para tokoh terkemuka yang turut menyuarakan aspirasinya. Terlihat mantan Menteri Kelautan dan Perikanan dari Kabinet Kerja 2014-2019, Susi Pudjiastuti mewarnai berita berhari-hari tentang isu impor beras ini.

Media berita online yang turut mengangkat pendapat dari para tokoh yang bertukar pendapat ini juga mengikutsertakan nama para tokoh dalam headline berita terkait wacana isu impor beras tersebut. Hal ini tentu menjadikan perbincangan terkait impor beras semakin memanas.

Rupanya banyak sekali warganet yang menyuarakan aspirasinya unutk menolak impor 1 juta ton beras oleh pemerintah Indonesia. Selain itu, banyak juga yang memberi dukungan kepada petani yang memiliki hasil panen yang melimpah. Banyak warganet yang mengutarakan kegelisahan dan kekecewannya terhadap pemerintah akibat pemerintah seolah tidak mau tahu ketika petani kesusahan dalam memperoleh benih dan pupuk yang dibanderol dengan harga yang cukup mahal. Bahkan petani di daerah Jawa Barat turut menyampaikan aspirasinya via zoom meeting untuk menunda bahkan menolak rencana impor 
beras ini. Ini artinya, isu penolakan impor 1 juta ton beras mendapatkan banyak dukungan dari netizen.

Warganet yang mendukung penolakan terhadap isu impor beras ini juga turut mengungkapkan kekecewaannya kepada pemerintah karena adanya wacana ini telah mengakibatkan harga gabah anjlok. Warganet terang-terangan membela nasib petani yang disengsarakan oleh pemerintah mengingat ketika akan menanam padi mereka harus membeli bibit dengan harga yang mahal, begitu juga dengan harga pupuk. Kemudin ketika masa panen raya malah pemerintah memutuskan untuk impor beras. Kekesalan warga ini sampai menimbulkan emosi ketika membahas bahwa impor beras ini dilakukan untuk menghadapi mafia. Bahkan warganet menantang supaya petani saja yang menghadapi mafia beras jika pemerintah sudah kalah menghadapi mafia beras.

Pemilik akun@PutraWadapi turut mengungkapkan kekecewaannya lewat tweet nya yang mengatakan bahwa bapak presiden selama 7 tahun lamanya diajak blusukan ke sawah sehingga menghadirkan citra pemimpin yang merakyat dan mencintai petani kini tengah mematahkan hati rakyat sebab mengumumkan wacana impor beras yang menjadikan rakyat kebingungan.

\section{Gambar 4.}

\section{Tren Berita Online}

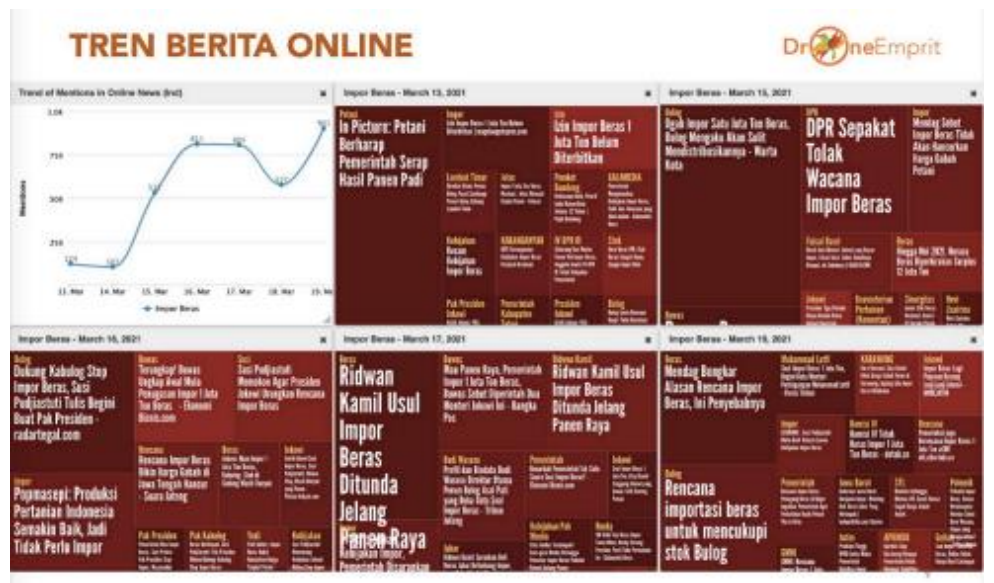

Sumber: diambil dari Drone Emprit

Selanjutnya media sosial (Twitter) dapat merekam narasi dari masingmasing opinion leader yang kemudiaan diikuti oleh pendukungnya melalui reetweet. Semakin tinggi reetwet yang terjadi menunjukan sikap aktor tersebut Jurnal Academia Praja Volume 4 Nomor 2 - Agustus 2021 
yang didukung oleh banyak netizen. Pada gambar 5 Susi Pujiastuti merupakan sosok yang paling banyak direetwet. Ini menunjukan konsistensi Pujisusiastuti untuk menolak dengan keras rencana impor beras didukung oleh banyak pengguna Twitter. Disisi lain jika diperhartikan secara seksama most reetwet mayoritas berasal dari tweet yang kontra dengan kebijakan impor beras. Bahkan beberapa diantaranya dikenal sebagai tokoh oposisi tulen pada pemerintahan Jokowi seperti Muhammad Said Didu, Tengku Zulkarnain dan Adhie Masardi. Artinya secara umum dan mayoritas publik Twitter menolak rencana ini.

\section{Gambar 5.}

Most Reetwed

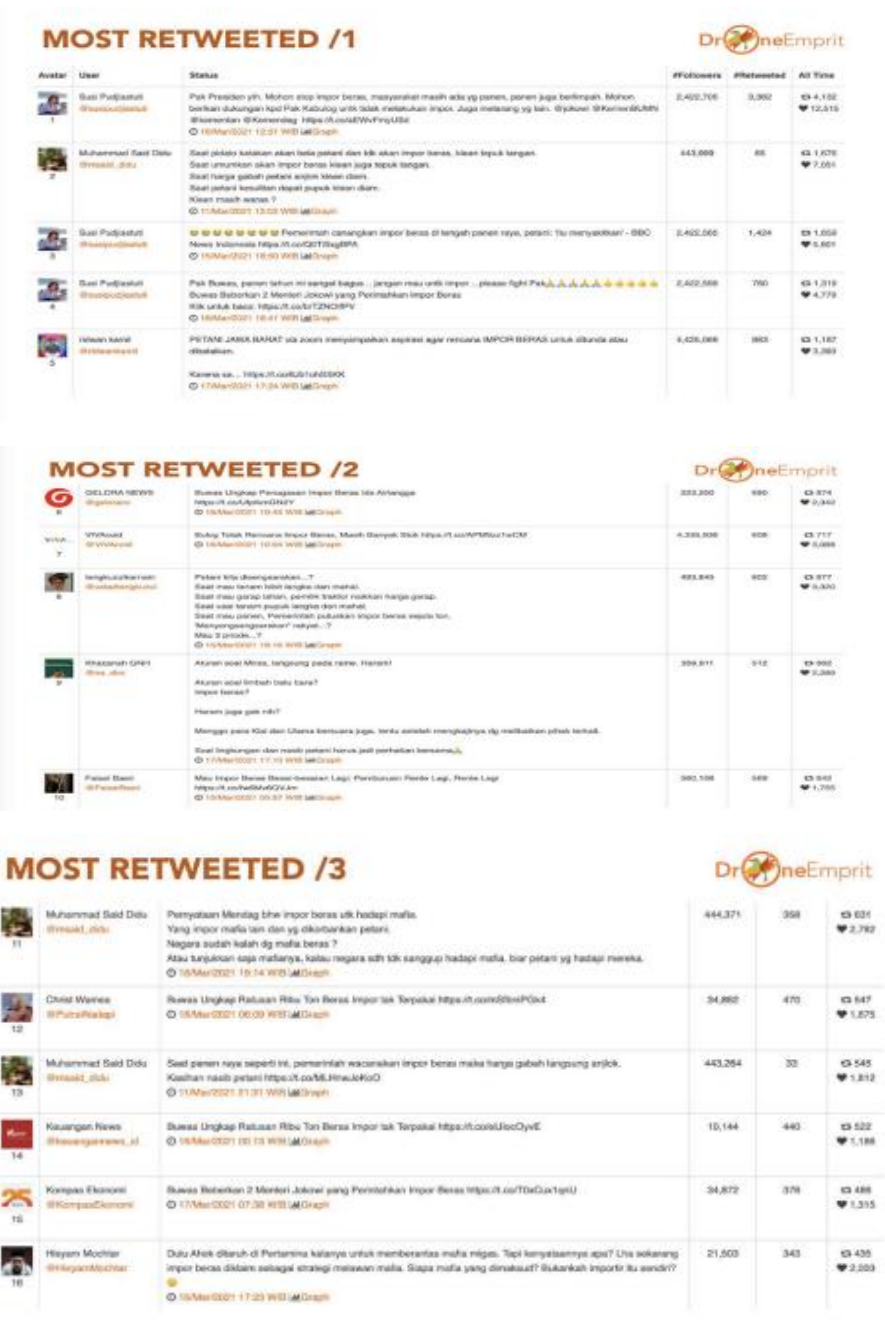




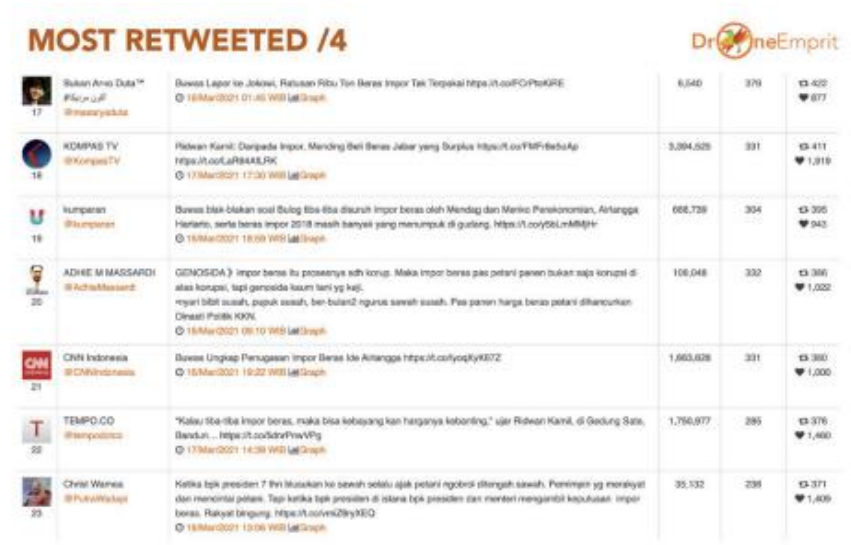

Sumber: diambil dari Drone Emprit

Dengan menggunakan Social Network Analysis (SNA) untuk melihat peta besar percakapan yang terjadi. Gambar 6 memperlihatkan hanya asa satu cluster besar dengan narasi utama menolak impor. Warna merah sebagai tanda resistensi disuarakan oleh beberapa tokoh-tokoh publik yang memang punya pengaruh terhadap persebaran dan keyakinan publik Twitter terhadap sebuah isu. Terlihat top

influencers: @susipudjiastuti, @ridwankamil, @Amal_Alghozali, @na_dirs,@Fa isalBasri, dll.

\section{Gambar 6.}

SNA Percakapan Impor Beras

SNA "IMPOR BERAS": SEMUA KONTRA

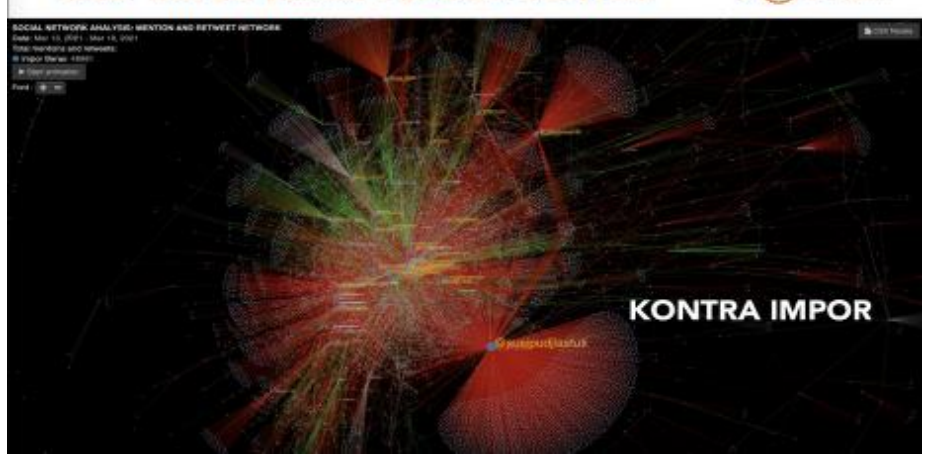

Sumber: diambil dari Drone Emprit

Selanjutnya jika dilihat dari ego network yang dimiliki oleh beberapa top influencer, berdasarkan data yang diperoleh dari Drone Empirt salah satu tokoh sekaligus influencer yang memiliki sambutan paling banyak dapat dijumpai pada ego networknya adalah Mantan Menteri Kelautan Indonesia yakni Susi 
Pudjiastuti. Namun meskipun memiliki pengaruh yang cukup besar pada ego networknya nyatanya tidak semua followernya ikutan dalam kluster netizen yang menolak atau kontra terhadap isu tersebut.

Beberapa tokoh yang memiliki pengaruh yang cukup besar juga, seperti halnya Ridwan Kamil pun, jika dilihat dari followernya, ternyata juga tidak semua ikut di dalam percakapan yang menunjukkan sikap kontra terhadap rencana kebijakan pemerintah tersebut. Namun ada beberapa akun juga, yang followersnya atau pengikutnya, disana menunjukkan ikut andil di dalam kluster penolakan atau kontra. Dari penemuan yang diperoleh dari Drone Emprit dapat dilihat akun bernama@PutraWadapidan@ustadtengkulzul merupakan beberapa tokoh yang mempunyai pengikut dan ikut aktif menyuarakan penolakan.

\section{Gambar 7.}

Ego Network Beberapa Top Influencer

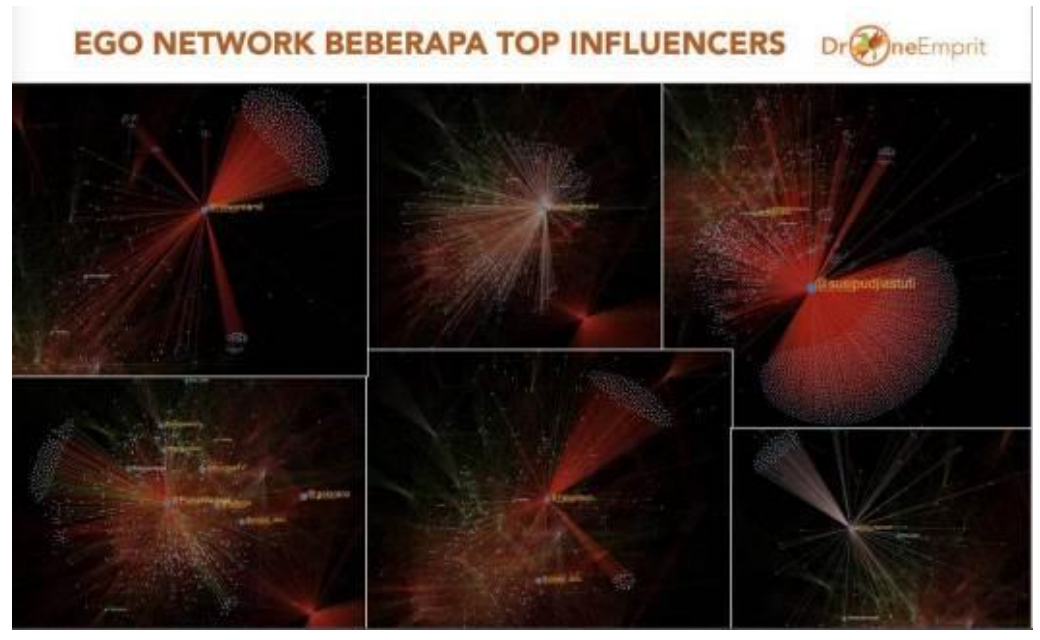

Sumber: diambil dari Drone Emprit

Lebih lanjut dari top 5 influencers yang di dalamnya termasuk ada Susi Pudjiastuti yang menempati posisi pertama yang mendapatkan sambutan tinggi oleh netizen sebanyak (7.344 engagement), kemudian disusul oleh Ridwan Kamil yang mendapatkan 1.298 engagements pada akun twiternya, Ustad Tengkuzul yang berada pada posisi ketiga dengan 1.195 engagement, selanjutnya ada Dandy Laksono dengan 1.173 engagements dan yang terakhir Putra Wadapi dengan capaian engagements sebanyak 1.154. Dari engagement yang diperoleh oleh setiap influencer tersebut tentunya sesuai dengan reaksi masyarakat atau netizen 
terhadap segala aktivitas di medsosnya dan juga terkait jumlah followers di media social yang mereka miliki.

\section{Gambar 8.}

Top Influencer

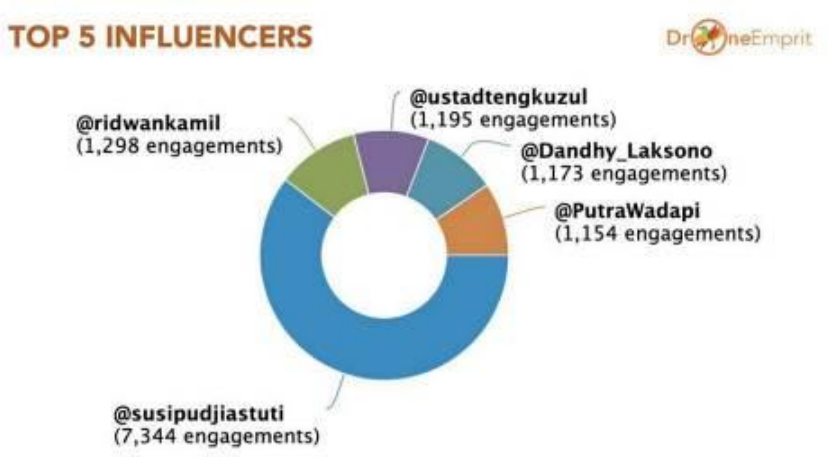

Sumber: diambil dari Drone Emprit

Jika dikembangkan menjadi 30 akun (gambar 9) yang memiliki influence dalam masyarakat seperti para pejabat, public figure, dan juga akun-akun penyedia berita nasional. Dilihat bahwa akun @susipudjiastuti menjadi akun nomor satu yang mendapatkan retweet sebanyak 7,344 itu disebabkan karena memang masyarakat sudah mengetahui pudji astuti sebagai mantan pejabat di Indonesia dan juga public figure yang sering mengkritik kebijakan-kebijakan kontroversi dari pemerintah.

\section{Gambar 9.}

\section{Top 30 Influencers}

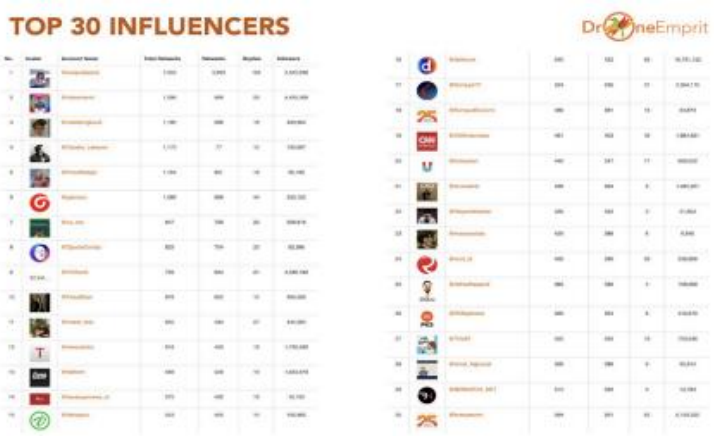

Sumber: diambil dari Drone Emprit

Hal menarik yang bisa dilihat dari gambar diatas juga adalah jika kita membandingkan jumlah followers yang ada di tiap akunnya sangat beragam, 
namun jumlah followers bukan aspek utama dalam kasus ini karena dapat dibuktikan seperti akun-akun publik figur yang memiliki jumlah followers di bawah akun penyedia berita nasional bisa lebih banyak dalam jumlah retweet, ini dapat disebabkan bukan karena hanya siapa yang berpendapat tapi apa isi pendapatnya, jika pendapat yang diungkapkan sangat bagus dan cenderung mewakili suara rakyat maka tak heran jika akan mendapatkan jumlah retweet yang banyak dari masyarakat.

\section{Gambar 10.}

Analisis Emosi Disgusting

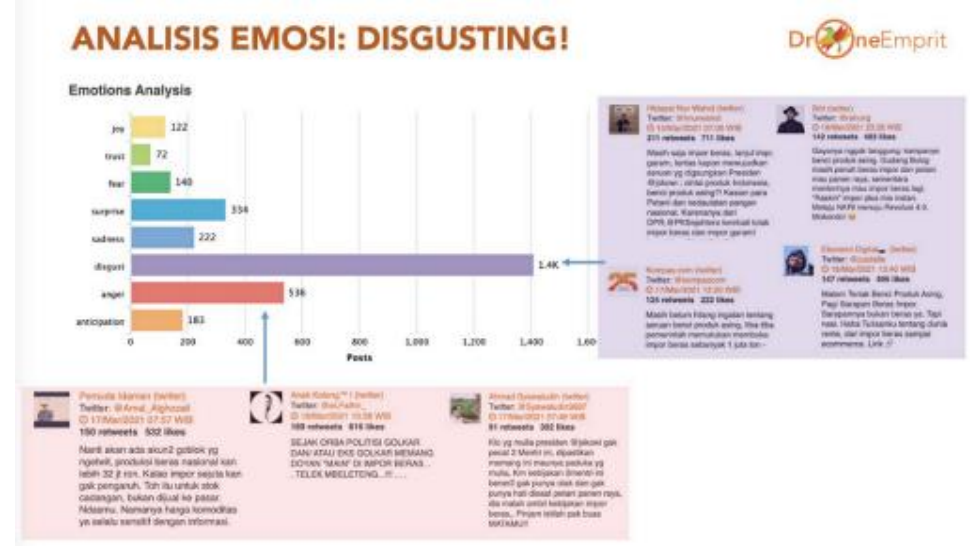

Sumber: diambil dari Drone Emprit

Bisa kita lihat dari gambar diatas bahwa emosi publik yang sangat dominan pada isu impor beras ini adalah disgust atau menjijikan. Mereka banyak yang menghubungkan dengan pernyataan pak @jokowi yang pernah mengatakan "benci" terhadapat produk asing, namun realita dilapangannya adalah banyak menterinya yang masih suka impor. Inkonsistensinya yang terjadi antara ungkapan dari seorang presiden dengan apa yang dilakukan oleh para menterinya lah yang sangat memancing emosi publik, emosi yang ditunjukan oleh masyarakat ini merupakan hal yang sangat wajar terjadi, karena mereka merasa pemerintah tidak bisa menyelaraskan pandangan menjadi satu dan masyarakat akan mengkhawatirkan bagaimana negara kedepannya.

Kedua yang paling dominan adalah emosi marah. Salah satu yang sangat marah adalah sebuah akun (@Amal_Alghozali) dengan avatar berkacamata gelap dan topi koboi. Marah melihat pejabat yang dapat seenaknya berwacana tanpa 
merasa menyusahkan petani dengan rencana impor saat panen. Dengan narasi kerasnya itu kita bisa melihat betapa marahnya pemiliki akun tersebut, dan tentu emosi marahnya pemilik akun tersebut sangat mewakili perasaan masyrakat luas yang juga marah namun tidak berani mengungkapkanya di sosial media.

Lalu emosi yang berada di urutan ketiga adalah surprise dan dilanjutkan ke emosi sadness, anticipation, fear, joy, trust. Dari seluruh emosi yang ada tersebut bahwa bisa disimpulkan masyarakat tidak sepakat akan rencana impor beras ini karena dinilai akan lebih membawa dampak negatifnya disbanding dampak positifnya, terlebih dampak besarnya akan sangat mengenai para petani yang bercocok tanam adalah mata pencaharian mereka sehari-hari.

\section{KESIMPULAN}

Berdasarkan data yang diperoleh dari Drone Emprit dapat ditarik satu benang merah, bahwa alasan mengapa isu kebijakan impor beras ini menjadi ramai dipercincangkan oleh berbagai kalangan masyarakat adalah, pertama rencana kebijakan impor dinilai akan merugikan petani lokal, jika harga beras impor jauh lebih rendah dari harga beras petani lokal. Kedua, masyarakat atau netizen masih menganggap pasokan kebutuhan beras di Indonesia masih cukup untuk memenuhi permintaan pasar, hal ini kemudian diperkuat dengan pernyataan kepala bulog Indonesia yakni Budi Waseso yang menyebutkan bahwasanya pasokan beras yang ada digudang bulog masih menumpuk dan belum terdistribusikan, selain itu beras-beras tersebut ternyata adalah beras hasil impor dari tahun 2017/2018.

Dengan demikian maka umur beras tersebut sudah lebih dari 2 tahun dan pastinya secara mutu dan kualitasnya pun sudah menurun. Warganet pun emosi dan kecewa dengan inkonsistensi pemerintah yang tidak berpihak kepada kesejahteraan petani lokal. Ketiga, pengaruh aktivitas inlfuencer pada ego networknya yang memberi dukungan kepada petani yang memiliki hasil panen yang melimpah. Aktivitas seorang influencer akan selalu mendapat banyak perhatian dan sambutan dari netizen. Entah itu sambutan yang mengarah pada pro ataupun kontra. Melalui ego network yang dimiliki oleh beberapa influencer 
seperti halnya Susi Pudjiastuti, Ridwan Kamil, seakan menjadi support system dalam meningkatkan kuantitas isu untuk diperbincangkan. Inilah mengapa kemudian isu adanya kebijakan impor beras langsung mendapatkan banyak perhatian dari berbagai kalangan masyarakat.

\section{DAFTAR PUSTAKA}

Adinugroho, I., Sjahputri, S., Budiarto, J., \& Muhamad, R. (2017). Technology, Emotion and Democracy: Understanding The Dynamic Through Analyzing Conversation in Twitter. Journal of Government and Politics, 8(1). https://doi.org/10.18196/jgp.8151

Amrullah, A. A., Tantoni, A., Hamdani, N., Bau, R. T. R. L., Ahsan, M. R., \& Utami, E. (2016). Reviewatas Analisis Sentimen Pada Twitter Sebagai Representasi Opini Publik Terhadap Bakal Calon Pemimpin. Prosiding Seminar Nasional Multi Disiplin Ilmu \& Call for Papers Unisbank (Sendi_U), 2(1), 978-979.

Annur, C. M. (2020). Sektor Pertanian Paling Banyak Menyerap Tenaga Kerja Indonesia. In Databoks (Issue November, p. 2020). Sektor Pertanian Paling Banyak Menyerap Tenaga Kerja Indonesia \%7C Databoks

Astiningrum, M., Batubulan, K. S., \& Sias, L. A. (2020). Implementasi Analisis Sentimen Twitter Mengenai Opini Masyarakat Terhadap RKHUP Tahun 2019. Seminar Informatika Aplikatif Polinema (SIAP) - 2020

Best, M. L., \& Meng, A. (2015). Twitter Democracy: Policy versus Identity Politics in Three Emerging African Democracies. ACM International Conference Proceeding Series, 15. https://doi.org/10.1145/2737856.2738017

Ceron, A., \& Memoli, V. (2016). Flames and Debates: Do Social Media Affect Satisfaction with Democracy? Social Indicators Research, 126(1), 225240. https://doi.org/10.1007/s11205-015-0893-x

Chrona, S., \& Bee, C. (2017). Right to Public Space and Right to Democracy: The Role of Social Media in Gezi Park. Research and Policy on Turkey, 2(1), 49-61. https://doi.org/10.1080/23760818.2016.1272267

Daniels, G. (2016). South African Arab Spring or Democracy to Come? An Analysis of South African Journalists' Engagement with Citizenry through Twitter. 107-108. DOI:10.1007/978-3-319-40949-8

Darwanto, D. H., \& Rahayu, E. S. (2017). Analisis Faktor-Faktor Yang 
Mempengaruhi Impor Beras Indonesia. Caraka Tani: Journal of $\begin{array}{lll}\text { Sustainable } \quad \text { Agriculture, } & \text { 23(1), }\end{array}$ https://doi.org/10.20961/carakatani.v23i1.13732

Davidson, J. S. (2018). Rice Imports and Electoral Proximity: The Philippines and Indonesia Compared. Pacific Affairs, 91(3), 445-470. https://doi.org/10.5509/2018923445

W., Aggasi, A., \& Ningtiyas, F. W. (2019). Pola Komunikasi Militer Dalam Program Swasembada Pangan di Wilayah Koramil 1607/-01 Sumbawa. Jurnal Tambora, 3(2), 66-74.

Febriaty, H. (2016). Analisis Perkembangan Impor Beras Di Indonesia. EKONOMIKAWAN: Jurnal Ilmu Ekonomi Dan Studi Pembangunan, 16(2), 134-141. https://doi.org/10.30596/ekonomikawan.v16i2.941

Galuh, I. G. A. A. K. (2016). Media Sosial sebagai Strategi Gerakan Bali Tolak Reklamasi. Jurnal Ilmu Komunikasi, 13(1), 73-92. https://doi.org/10.24002/jik.v13i1.602

Hasfi, N., Usmand, S., \& Santoso, H. P. (2017). Anonimitas di Media Sosial: Sarana Kebebasan Berekspresi atau Patologi Demokrasi? Jurnal Ilmu Komunikasi, 15(1), 28. https://doi.org/10.31315/jik.v15i1.2152

Ikhsani, I. I. I., Tasya, F. E., Sihidi, I. T., Roziqin, A., \& Romadhan, A. A. (2020). Arah Kebijakan Sektor Pertanian di Indonesia untuk Menghadapi Era Revolusi Industri 4.0. Jurnal Administrasi Dan Kebijakan Publik, 5(2), 134-154. https://doi.org/10.25077/jakp.5.2.134-154.2020

Impor, A., \& Di, B. (2014). Analisis Impor Beras Di Indonesia. Economics Development Analysis Journal, 3(2), 320-326. https://doi.org/10.15294/edaj.v3i2.3838

Jha, C. K., \& Kodila-Tedika, O. (2020). Does social media promote democracy? Some empirical evidence. Journal of Policy Modeling, 42(2), 271-290. https://doi.org/10.1016/j.jpolmod.2019.05.010

Juditha, C. (2014). Opini Publik Terhadap Kasus "KPK Lawan Polisi” dalam Media Sosial Twitter. Jurnal Pekommas, 17(2), 61-70.

Justwan, F., Baumgaertner, B., Carlisle, J. E., Clark, A. K., \& Clark, M. (2018). Social Media Echo Chambers and Satisfaction with Democracy Among Democrats and Republicans in the Aftermath of the 2016 US Elections. Journal of Elections, Public Opinion and Parties, 28(4), 424-442. https://doi.org/10.1080/17457289.2018.1434784 
Lee, P. S. N., So, C. Y. K., Lee, F., Leung, L., \& Chan, M. (2018). Social Media and Political Partisanship - a Subaltern Public Sphere's Role in Democracy. Telematics and Informatics, 35(7), 1949-1957. https://doi.org/10.1016/j.tele.2018.06.007

Loilatu, M. J., Irawan, B., Salahudin, S., \& Sihidi, I. T. (2021). Analysis of Twitter's Function as a Media Communication of Public Transportation. Jurnal Komunikasi, 13(1), 54. https://doi.org/10.24912/jk.v13i1.8707

Paipan, \& Abrar. (2020). Determinan Ketergantungan Impor Beras di Indonesia [Determinants of Rice Import Dependency in Indonesia]. Jurnal EKP, Vol. 11,(No. 1), 53-64.

Placek, M. A. (2017). \#Democracy: Social Media Use and Democratic Legitimacy in Central and Eastern Europe. Democratization, 24(4), 632650. https://doi.org/10.1080/13510347.2016.1202929

Prasetya, ikri H., \& Yudha, M. (2021). Bulog Tolak Rencana Impor Beras, Masih Banyak Stok. Vivanews.Com. https://www.viva.co.id/berita/bisnis/1356210-bulog-tolak-rencana-imporberas-masih-banyak-stok

Pratama Kusumah, F. (2019). Ekonomi Politik dalam Kebijakan Impor Beras: Membaca Arah Kebijakan Pemerintah 2014-2019. POLITIKA: Jurnal Ilmu Politik, Vol.10, No(Ekonomi Politik), 137-162. https://doi.org/10.14710/politika.10.2.2019.137-162

Pratiwi, Bungin, B. S. (2015). Kebebasan Berpendapat Melalui Facebook Dan Twitter: Studi Kasus Undang-Undang Informasi dan Transaksi Elektronik. Jurnal Representamen, l(1). https://doi.org/10.30996/representamen.v1i01.1440

Purnomo, E. P., Loilatu, M. J., Nurmandi, A., Salahudin, Qodir, Z., Sihidi, I. T., \& Lutfi, M. (2021). How Public Transportation Use Social Media Platform during Covid-19: Study on Jakarta Public Transportations' Twitter Accounts? Webology, 18(1), 1-19. https://doi.org/10.14704/WEB/V18I1/WEB18001

Rahman, A. (2021). Impor Beras Ramai-Ramai Ditolak. Droneemprit.Id. https://pers.droneemprit.id/impor-beras-ramai-ramai-ditolak/

Rondhi, M., Khasan, A. F., Mori, Y., \& Kondo, T. (2019). Assessing the Role of the Perceived Impact of Climate Change on National Adaptation Policy: The Case of Rice Farming in Indonesia. Land, 8(5). https://doi.org/10.3390/land8050081 
Sa'diah, S. A., \& Tamami, N. D. B. (2020). Proyeksi Ekspor Beras Nasional Melalui Gerakan Tiga Kali Lipat Ekspor (Gratieks) Pertanian Indonesia. Pamator Journal, 13(2), 159-169. https://doi.org/10.21107/pamator.v13i2.8527

Sains, J., Pangan, T., Ketersediaan, A., Dengan, B., Sistem, P., The, I., Of, V., District, T., Laeya, O., Regency, T., \& South, O. (2021). Analisis Ketersediaan Beras Dengan Pendekatan Sistem Dinamik di Kelurahan Punggaluku Kecamatan Laeya Kabupaten Konawe Selatan. Jurnal Sains dan Teknologi Pangan, 4(4), 2360-2378.

Salahudin, S., Nurmandi, A., Yogyakarta, U. M., \& Sulistyaningsih, T. (2020). Analysis of Government Official Twitters during Covid-19 Crisis in Indonesia Analysis of Government Official Twitters during Covid-19 Crisis in Indonesia. Talent Development \& Excellence, 12(1).

Somantri, A. S., Luna, P., Widi, I., \& Waryanto, B. (2020). Analisis Sistem Dinamik Untuk Evaluasi Pencapaian Swasembada Beras Melalui Program Upaya Khusus. Informatika Pertanian, 29(2), 95-110. DOI:10.21082/ip.v29n2.2020.p95-110

Timorria, I. F. (2019). Produksi Beras hingga September Diperkirakan Capai 26,91 Juta Ton. Ekonomi Bisnis.Com. https://ekonomi.bisnis.com/read/20190812/99/1135604/produksi-berashingga-september-diperkirakan-capai-2691-juta-ton\#: :text=Produksi beras dalam negeri diperkirakan,juta ton pada periode ini.

Widyawati, W., Syafrial, \& Mustadjab, M. M. (2014). Dampak Kebijakan Tarif Impor Beras Terhadap Kinerja Ekonomi Beras di Indonesia. Habitat, $X X V(2), 125-134$.

Wischmeyer, T. (2019). Making Social Media an Instrument of Democracy. European Law Journal, 25(2), 169-181. https://doi.org/10.1111/eulj.12312 